\title{
Obituary
}

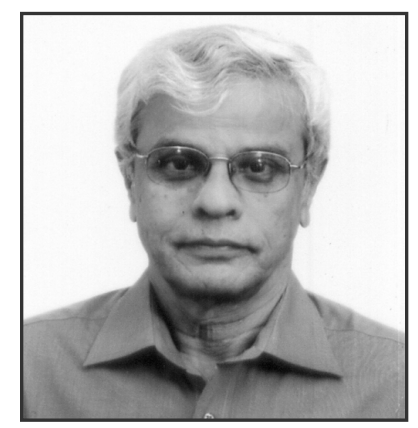

\section{Late Prof. Dr. Naiyyum Choudhury}

(1946-2019)

Professor Dr. Naiyyum Choudhury, Vice President of the Bangladesh Academy of Sciences (BAS), a distinguished scholar with a very bright academic career, vast experience in research, teaching administration and management, a dedicated scientist for promotion of excellence in science education and research expired on Saturday, 07 September 2019 (Inna Lillahi wa Inna Ilaihi Rajiun). Professor Choudury was born in Comilla on 27 September 1946.

Professor Choudhury did his BSc (Hons.) and MSc in Biochemistry in 1966 and 1967 respectively from the University of Dhaka. Professor Choudhury obtained his PhD from the school of Biotechnology, University of New South Wates, Australia in 1982 and Post-Doctoral Fellowship in 1988-89 at the Institute of Hygiene and Toxicology, University of Karlsruhe, Germany.

Professor Choudhury joined the then Pakistan Energy Commission in 1968 as Scientific Officer, became Member (Bio-sicnece) of Bangladesh Atomic Energy Commission in 1997 and its Chairman in 2002. He retired as Chairman of Bangladesh Atomic Energy Commission in 2003.

During late 1980s and early 1990s he was simultaneously a part-time teacher of the Department of Zoology, Jahangirnagar University, Department of Chemical Engineering, Bangladesh University of Engineering and Technology (BUET) and Department of Microbiology. He was involved in teaching Microbiology at the University of Dhaka since 1982 and was actively involved in opening a separate Department of Microbiology at DU. He joined the Department of Microbiology, DU as full-time Professor and Chairman in 1993. He was a guest Professor and then a part-time teacher in the Department of Genetic Engineering and Biotechnology, University of Dhaka. He was a Member of the Academic Council, University of Dhaka since 1997 and was Member of the Senate of the Dhaka University, 1998-2003. He was also a Senate Member of Jahangirnagar University, 2000-2003 and National University, 1999-2001. He was a Syndicate member of the BUET in 2003.

Professor Choudhury held many important positions in the Bangladesh Atomic Energy Commission prior to becoming its Member and then Chairman. He was Director of the Institute of food and Radiation Biology; Director of Biosciences; Director, Planning and Development and Director, International Affairs Division of the Bangladesh Atomic Energy Commission. He was the National Coordinator for Regional Cooperative Agreement (RCA) of the IAEA for Research, Training and Development in peaceful uses of nuclear science and technology in the East Asia and the Pacific region consisting of 17 Member States and was unanimously elected as its Chairman in the 30th General Conference of the RCA held in Vienna on 15-16 September for two years, only scientist from Bangladesh to hold this prestigious position. He made significant contribution in the field of food microbiology, microbial biotechnology, food irradiation and other peaceful uses of nuclear energy. 
He published more than 150 papers in national and international journals. He edited a number of International Symposia Proceedings and was the Editor-in-Chief of the Bangladesh Journal of Science and Technology and Editor of the Bangladesh Journal of Microbiology. He was a member of the Editorial Board of the Journal of Bangladesh Academy of Sciences and the Journal of NOAMI.

Professor Choudhury was intimately connected with many national and international scientific bodies. He was elected President of the Bangladesh Atomic Energy Scientists Association (BAESA) for consecutive two terms. He became a member of the New York Academy of Science and British Society for Applied Bacteriology in 1989. He was the President of a number of scientific professional bodies which include Bangladesh Association of Scientists and Scientific Professions (BASSP); Bangladesh Biochemical Society, Bangladesh Tissue Banking Association, Bangladesh Society of Microbiologists (BSM), and Bangladesh JSPS Alumni Association.

Professor Choudhury visited different countries of the world that include Australia, Austria, Canada, U.S.A., United Kingdom, China, Germany, Indonesia, India, Malaysia, Pakistan, Singapore, Japan, Jamaica, Korea, Saudi Arabia, South Africa, Myanmar, the Philippines, Thailand, Nepal, Sri Lanka, Egypt, Netherland, and Morocco in connection with higher studies, Seminars, Conferences, Workshops, Expert Group Meetings and Research Coordination Meetings.

Professor Naiyyum Choudhury was a member of National Biotechnology Productivity Committee formed by the Government of Bangladesh in 1993. He was Convener of the Committee for formulation of the National Biotechnology Policy 2005. He was actively involved in development of a concept paper for a Biotechnology Institute and was the founder Project Director of the National Institute of Biotechnology (NIB) built at Ganokbari, Savar. He was involved in drafting the National Bio-safety Guidelines in 1999 and then in 2005. He was also a member of the Biosafety Core Committee (BCC) of the government. He was the Convener of the Committee for formulation of the National Science and Technology Policy, 2011 of the Government of the People's Republic of Bangladesh and was Advisor of the Committee on formulation of the Action Plan of the Policy. He was a Member of the Executive Committee of the National Council for Science and Technology (ECNCST).

For his outstanding contribution in science, Professor Choudhury received the Bangladesh Journalists' Association Award, 2000 and Zaki Memorial Gold Medal Award, 2000. He was awarded the Bangladesh Academy of Sciences- Dr. MO Ghani Gold Medal in 2002 for his outstanding contribution in science and technology. He was elected Secretary of the Bangladesh Academy of Sciences for the period 2004-2007 and then reelected as Secretary for the period 2008-2011. Professor Choudhury served BRAC University as Professor and Coordinator of Biotechnology and Microbiology Programmes since 2005 and was a part-time faculty of the Department of Microbiology, University of Dhaka since its inception. At the time of his death he was the Chairman of the Bangladesh Atomic Energy Regulatory Authority (BAERA), Dhaka.

Professor Naiyyum Choudhury was the 3rd son of Late Abdul Jalil Choudhury of Noakhali Old Town and Late Sadia Begum. Professor Choudhury married in 1976 to Shamima Choudhury. She is a Professor in the Department of Physics and also Director, Bose Centre, University of Dhaka. His daughter Sarah Nahin Choudhury, MRCP (UK) is a physician in Manchester, UK and son, Sajid Muhaimin Choudhury is an Assistant Professor in the Department of EEE, Bangladesh University of Engineering and Technology (BUET).

In his death, the Academy lost a very active and dedicated fellow scientist and the nation a great son. We pray to the Almighty Allah, Most Gracious and Most Merciful, to grant eternal peace to the departed soul and to give strength and courage to the members of his family to bear the loss with fortitude.

- Mesbahuddin Ahmed 